Original Research Paper

\title{
CORRELATION BETWEEN BLOOD GLUCOSE LEVEL AND BODY MASS INDEX AMONG PREGNANT WOMEN WITH EXCESS BODY WEIGHT
}

\author{
Betharia Lorenza Br Surbakti*, Adek Amansyah, Juliana Lina \\ Faculty of Medicine, Universitas Prima Indonesia, Medan, Indonesia
}

\section{Email Corresponding:}

betharialorenza@gmail.com

Page : $35-40$

\section{Keywords:}

BGL, BMI, GDM, Royal Prima

Kata Kunci :

KGD, IMT, DMG, Royal Prima

\begin{abstract}
Amount of 207 million (83.6\%) women who give birth simultaneously are diagnosed with GDM in 2019. Prevalence of GDM reaches $1.9-3.6 \%$ in Indonesia. Amount of 40-60\% of GDM will suffer from postpartum NonDependent Insulin Diabetes Mellitus. Hence, this study was aimed to look for the distribution of blood sugar levels among pregnant women who are overweight. This research was performed among pregnant women in the Obstetrics and Gynecology polyclinic of Royal Prima Medan Hospital against 41 people as the sample with a cross-sectional model (Longitudinal study). The aspects evaluated in this study were age, gestational age, BMI, occupation, income, recent education, history of gestational DM, Macrosomia, and obstetrics. All research data was analyzed with SPSS 25 by spearman correlation. The trend of random et blood sugar levels of pregnant women as respondents was $100 \mathrm{mg} / \mathrm{dL}$, while the BMI tendency was $31.72 \mathrm{~kg} / \mathrm{m} 2$. Based on these parameters, they had a correlation with each other among overweight pregnant women (Value $P=$ $0.007)$ that was moderate $(R=0.417)$. Blood sugar levels were moderate correlated with BMI among pregnant women with excess body weight.
\end{abstract}

ABSTRAK
Pada tahun 2019 terdapat 207 juta $(83,6 \%)$ wanita yang melahirkan bersamaan
didiagnosa DMG. Prevalensi di Indonesia, kejadian DMG mencapai 1,9-3,6\%.
Sebanyak 40-60\% dari DMG akan mengalami Diabetes Mellitus Tipe 2 pasca
melahirkan. Sehingga, penelitian ini bertujuan untuk mengetahui gambaran kadar
gula darah ibu hamil yang memiliki berat badan berlebih. Penelitian ini dilakukan
pada ibu hamil di poliklinik Obstetri dan Ginekologi Rumah Sakit Umum Royal
Prima Medan terhadap 41 orang sebagai sampel penelitian dengan model Cross
sectional (Potong Lintang). Aspek-aspek yang dinilai dalam penelitian ini adalah
umur, usia kehamilan, IMT, pekerjaan, pendapatan, pendidikan terakhir, riwayat
DM gestasional, macrosomia, dan obstetric. Seluruh data penelitian dianalisa
dengan SPSS 25 dan dianalisa dengan menggunakan korelasi spearman.
Kecenderungan kadar gula darah et random dari ibu hamil sebagai responden
adalah 100 mg/Dl, sedangkan kecenderungan IMT adalah 31.72 kg/m2. Dari
kedua parameter tersebut, terdapat korelasi antara IMT dan kadar gula darah pada
ibu hamil dengan berat badan berlebih (Nilai P = 0.007), korelasi antar kedua
variabel bersifat cukup kuat (R = 0.417). Kadar gula darah cukup kuat berkorelasi
dengan IMT pada kelompok ibu hamil dengan berat badan berlebih.

Published by:

Tadulako University,

Managed by Faculty of Medicine.

Email: healthytadulako@gmail.com

Phone (WA): +6285242303103

Address:

Jalan Soekarno Hatta Km. 9. City of

Palu, Central Sulawesi, Indonesia

\section{INTRODUCTION}

Several studies have been performed to evaluate the effect of blood glucose level against the body weight. Gou et al. (2019) reported that fasting blood glucose after 1 to 2 hour consume 75-gram glucose showed a significant difference at various degrees of excess body weight pregnant women (P-Value
$<$ 0.05). Furthermore, Bloomgarden (2010) also reported that not only blood glucose but also the level of HbA1C significantly increase among pregnant women with an excess of increasing body weight $(\mathrm{P}-\text { Value }<0.05)^{1,2}$.

It becomes clear whether blood glucose level might affect the body weight among pregnant women. The increase of blood 
glucose level and body weight among pregnant women is a risk factor for Gestational Diabetes Mellitus. Gestational Diabetes Mellitus (GDM) is classified as the type of diabetes Mellitus. GDM is an intolerance glucose condition that is found at the pregnant period (the most of case within 24 weeks of gestation age). ${ }^{34}$.

GDM is a severe problem not only in Indonesia but also over the world. International Diabetes Federation (2019) reported that the case of diabetes would increase significantly every year until 2045. It estimates 463 million people at 20-79 years old over the world will suffer from diabetes, and around $79.4 \%$ of them were lived at the low to middle-income countries. Meanwhile, the number of pregnant women that suffer from GDM in 2019 was around 207 million $(83.6 \%)$ women that birth alive ${ }^{3}$. Furthermore, the rate of GDM in Indonesia was 1.9 to $3.6 \%$, and the amount of $40-60 \%$ of them suffered from Non-Insulin Dependent Diabetes Mellitus after giving birth ${ }^{5,6}$.

Uncontrolled of GDM among pregnant women may lead to various morbidity and mortality. These conditions include maternal or fetal complication for the short or long term that leads to potential maternal and fetal death $5,67,8$

Based on the information above, it becomes important to early prevention of the GDM. This study was performed to explore the relationship between the blood glucose level and body mass index among pregnant women with excess body weight.

\section{METHOD}

This study was an observational study with cross-sectional design in the Obstetrics and Gynecology Polyclinic of Royal Prima Hospital in Medan at June-October 2020.

This study has been approved by the director of the hospital with letter no.
1062/EXT/PP/RSURP/VI/2020 and the Health Research Ethics Committee from Universitas Prima Indonesia with registration no. 028/KEPK/UNPRI/V/2020.

The population of this study was all pregnant women in first to the third trimester in the Obstetrics and Gynecology Polyclinic of Royal Prima Hospital in Medan.

The number of sample in this study was determined by the following formulation ${ }^{9}$ :

$$
\begin{gathered}
\mathrm{N}=\left[2 \frac{z_{\alpha} \times P(1-P)}{W}\right]^{2} \\
\mathrm{~N}=\left[2 \frac{1.96 \times 0.09(1-0.09)}{0.05}\right]^{2} \\
\mathrm{~N}=\left[2 \frac{1.96 \times 0.09(0.91)}{0.05}\right]^{2} \\
\mathrm{~N}=\left[2 \frac{1 . .96 \times 0.08}{0.05}\right]^{2} \\
\mathrm{~N}=\left[2 \frac{0.16}{0.05}\right]^{2}=[2(3.2)]^{2}=[6.4]^{2} \\
\mathrm{~N}=40.96 \sim 41 \text { women }
\end{gathered}
$$

$Z_{\alpha}, P$, and were $Z$-Score for $\alpha=0.05$, Proportion of high blood glucose among pregnant women in the previous study (0.09), and allowable error (5\%), respectively.

Forty-one women as the sample were selected by the disproportional stratified random sampling. It was selected sample from a population by stratifying them not proportionally from each strata. The strata were the number of the month along the time of this study (3 months). Hence, the sample was selected for 14 women every month.

All data in this study was collected by a questionnaire about body weight and height before pregnancy, gestational age, the highest level of education, history of diabetes mellitus in family, history of Macrosomia and GDM, average earnings of the household, and personal identity. The body weight and height of pregnant women before pregnancy was collected from the medical record.

On the other hand, this study was also used an observational sheet included blood glucose level, body weight, height, Body Mass 
Index (BMI), and height of fundus. BMI was determined by divided the body weight $(\mathrm{kg})$ to the square of height (m). A glucometer measured the blood glucose level (Autocheck ()). Meanwhile, the height of fundus was measured by body measuring tape.

Initially, all pregnant women, as the sample were told about the purpose, protocol, and confidentiality of this study. After pregnant woman agreed to join to this study, the capillary blood was collected by pen lancet, and it was determined the level of blood glucose by glucometer. After that, their body weight and height were measured. At last, the pregnant woman was interviewed by the questionnaire.

All data in this study were analyzed by IBM SPSS 25. All data were firstly analyzed descriptively. After that, it was continued to correlation analyses based on the normality of data. If the data distributed normally, it was analyzed by Pearson correlation, instead of spearman correlation.

\section{RESULT}

This study was performed against 41 pregnant women with excess body weight that have agreed to join this study, and the following table showed the characteristic of the sample.

Table 1. Characteristics of Pregnant Women as Sample

\begin{tabular}{|c|c|c|}
\hline Parameters & Frequency & Percentage \\
\hline $\begin{array}{c}\text { Age (Mean } \pm \\
\text { SD) }\end{array}$ & 27.02 & \pm 3.57 \\
\hline
\end{tabular}

\section{Gestation age}

(Median)

$29.00(14.00)$

(Range)

\begin{tabular}{ccc}
\hline \multicolumn{3}{c}{ Body Massa Index $\left(\mathbf{k g} / \mathbf{m}^{\mathbf{2}}\right)$} \\
\hline Overweight & 20 & 48.9 \\
Obesity class I & 10 & 24.4 \\
Obesity class II & 8 & 19.5 \\
Obesity class III & 3 & 7.3 \\
\hline
\end{tabular}

Blood Glucose Level (mg/dL)

\begin{tabular}{|c|c|c|}
\hline $\begin{array}{l}\leq \text { Median }(99.50 \\
\mathrm{mg} / \mathrm{dL})\end{array}$ & 20 & 48.8 \\
\hline $\begin{array}{l}>\text { Median }(99.50 \\
\mathrm{mg} / \mathrm{dL})\end{array}$ & 21 & 51.2 \\
\hline \multicolumn{3}{|c|}{ Occupation } \\
\hline Housewife & 22 & 53.7 \\
\hline $\begin{array}{l}\text { Government } \\
\text { employee }\end{array}$ & 11 & 26.8 \\
\hline Self-employed & 8 & 19.5 \\
\hline \multicolumn{3}{|c|}{ Earning of the household (IDR/Bulan) } \\
\hline None & 22 & 53.7 \\
\hline $\begin{array}{c}\leq \text { Mean } \\
(3.247 .368 \text { IDR/ } \\
\text { Bulan })\end{array}$ & 13 & 31.7 \\
\hline $\begin{array}{c}>\text { Mean } \\
(3.247 .368 \mathrm{IDR} / \\
\text { Bulan })\end{array}$ & 6 & 14.6 \\
\hline \multicolumn{3}{|c|}{ The Highest Level of Education } \\
\hline Primary school & 7 & 17.1 \\
\hline $\begin{array}{l}\text { Junior High } \\
\text { School }\end{array}$ & 5 & 12.2 \\
\hline $\begin{array}{l}\text { Senior High } \\
\text { School }\end{array}$ & 13 & 31.7 \\
\hline College/University & 16 & 39.0 \\
\hline \multicolumn{3}{|c|}{$\begin{array}{c}\text { History of Diabetes Mellitus (DM) in } \\
\text { Family }\end{array}$} \\
\hline No & 22 & 53.7 \\
\hline Yes & 19 & 46.3 \\
\hline \multicolumn{3}{|c|}{ History of Macrosomia } \\
\hline No & 27 & 65.9 \\
\hline Yes & 14 & 34.1 \\
\hline
\end{tabular}

History of Obstetrics

Gravidarum (G)

$\begin{array}{lll}\text { Primigravida } & 11 & 26.8 \\ \text { Multigravida } & 30 & 73.2\end{array}$

\begin{tabular}{ccc} 
Parity (P) & & \\
\hline Primipara & 18 & 43.9 \\
Multipara & 12 & 29.3
\end{tabular}

\begin{tabular}{ccc}
\hline $\begin{array}{c}\text { Abortion (A) } \\
\text { None }\end{array}$ & 37 & 90.2 \\
Yes & 4 & 9.8 \\
\hline Based on the table above, most of the \\
pregnant women that joined this study had an \\
average age of 27.02 years old with an average
\end{tabular}


of 29 weeks of gestational age. All sample had excess body weight before pregnancy; most of them had overweight $(48.9 \%)$ when the period of the study was performing. Social demography characteristic of the sample showed that all sample had worked as a housewife $(53.7 \%)$ with none annual earning of household $(53.7 \%)$. Most of the sample also had the highest level of education as a college/university (39\%).

Furthermore, other characteristics that were also evaluated viz. a history of DM in family, Macrosomia, and obstetric as the characteristics of the sample. The most of sample in this study did not have a history of Macrosomia $(65.9 \%)$ or DM $(53.7 \%)$ in the family. Meanwhile, the history of obstetric of the sample showed that most of the sample was Multigravida (73.2\%), multipara (73.2\%), and none abortion history (90.2\%).

After evaluating the characteristic of the sample, the analysis was continued to Spearman correlation due to the blood glucose level, and BMI was not distributed normally. The following table showed the result of the analysis.

Table 2. Spearman Correlation Analysis of Blood Glucose Level and BMI

\begin{tabular}{|c|c|c|c|c|}
\hline Parameter & Median & Range & $\begin{array}{c}\text { P- } \\
\text { Value }\end{array}$ & $\mathbf{r}$ \\
\hline Blood & & 125.00 & \multirow{4}{*}{0.007} & \multirow{4}{*}{0.417} \\
\hline Glucose & 100.00 & (78- & & \\
\hline Level & & 203.00) & & \\
\hline BMI & 30.18 & $\begin{array}{c}14.67 \\
(25.96- \\
40.63)\end{array}$ & & \\
\hline
\end{tabular}

Based on the table above, there was a significant correlation between the blood glucose level and BMI. It due to the P-Value < 0.05 (P-Value $=0.007)$. Moreover, the $\mathrm{r}$ as correlation coefficient implies the direction and power of the correlation. This study showed that the correlation coefficient between Blood glucose level and BMI was 0.417 ; it means that the correlation was a moderate positive correlation.

\section{DISCUSSION}

The result of this study has achieved the purpose of this study to look for the relationship between the blood glucose level and BMI among pregnant women with excess body weight. The blood glucose level significantly affects the BMI among pregnant women with excess body weight. The correlation between blood glucose and BMI was moderate; when the blood glucose level increases, it will increase the BMI among pregnant women with excess body weight. It means that the increase or decrease in blood glucose level will cause an increase or decrease in BMI, respectively.

The physiology change and insulin resistance during pregnancy may be responsible for the correlation between blood glucose and BMI in this study. These changes are caused by high concentrations of steroid hormones: progesterone, estrogen, prolactin, cortisone, and human placental lactogen. All of these hormones can cause a decrease in the sensitivity of insulin receptors to target organs. It shows as the increase of blood glucose level to Gestational diabetes mellitus in varying severity that occurs in pregnancy ${ }^{10}$.

There was a limited number of study that explore the effect of blood glucose level and BMI; most of study looked for the relationship between GDM and IMT. Id et al. (2019) reported a similar result to this study. Id et al. (2019) reported that the BMI significantly affect to develop of Non-Dependent Insulin Diabetes Mellitus (P-Value $=0.001)$. Other factors also affected to develop of NonDependent Insulin Diabetes Mellitus like hip and waist circumference, blood glucose level (Fasting or oral glucose tolerance test), and oral hypoglycemic medication ${ }^{11}$.

The most of studies looked for GDM and 
BMI, Yong et al. (2020) reported that maternal age and BMI at the first prenatal care had a significant independent association with risk of GDM. Overweight / obese women (OR = $1.44,95 \% \mathrm{CI}=1.04-1.81)$ had a significantly higher risk of GDM than women with underweight / normal weight. No significant independent effect was observed between pregnancy weight gain in trimesters 1 and 2 and the risk of GDM ${ }^{12}$.

The latest study that was performed by Winardo et al. (2020) reported whether other factors affect the BMI among pregnant women. These were lipid profile. There was a significant correlation between BMI and total cholesterol ( $\mathrm{p}=0.013 ; \mathrm{r}=0.371)$. Moreover, the LDL and total cholesterol were also significantly correlated to fasting blood glucose. Hence, it was obvious that BMI, blood glucose and lipid profile were correlated with each other. In additional, Winardo et al. (2020) also reported that the incidence of gestational diabetes mellitus was $2.38 \%$ of all second-trimester pregnancies ${ }^{10}$

\section{CONCLUSION}

Overall, the blood glucose level was correlated positively against the BMI among pregnant women with excess body weight before getting pregnant. Further investigation was required to looking for the correlation among all pregnant women with various body weight.

\section{ACKNOWLEDGMENT}

Authors are most thankful for Royal Prima General Hospital Directors that has allowed and supported this study.

\section{REFERENCES}

1. Gou BH, Guan HM, Bi YX, Ding BJ. Gestational diabetes: Weight gain during pregnancy and its relationship to pregnancy outcomes. Chin Med J (Engl). 2019;132(2):154-160. doi:10.1097/CM9.0000000000000036
2. Bloomgarden ZT. Gestational diabetes mellitus and obesity. Diabetes Care. 2010;33(5):5-9. doi:10.2337/dc10-zb05

3. Diabetes Federation International. IDF Diabetes Atlas 2019.; 2019.

4. Motha C, Dias T. Diabetes mellitus in pregnancy. Sri Lanka J Obstet Gynaecol. Published online 2015:1-6.

5. Purnamasari D, Waspadji S, Adam J, Rudijanto A, Tahapary D. Indonesian Clinical Practice Guidelines for Diabetes in Pregnancy. J ASEAN Fed Endocr Soc. 2013;28(1):9-13.

6. Dewi AMS, Tiho M, Kaligis SHM. Gambaran Kadar Glukosa Darah Sewaktu Pada Ibu Hamil Trimester III Di Rumah Sakit Robert Wolter Mongisidi Manado. J Med Dan Rehabil. 2018;1(2):1-4.

7. Kiani F, Naz MSG, Sayehmiri F, Sayehmiri K, Zali H. The Risk Factors of Gestational Diabetes Mellitus: A Systematic Review and Meta-Analysis Study. Int J Women's Heal Reprod Sci. 2017;5(4):253-263.

8. Lumadi SA, Sulaiman K. Penerapan Penilaian Faktor Risiko Diabetes Mellitus Tipe 2 Pada Ibu Hamil Trimester 2 Dan 3. J Nurs Care Biomol. 2017;2(1):42-47.

9. Widiana IGR. Aplikasi Statistik Pada Peneltiian Kedokteran. EGC; 2015.

10. Winardo DS, Wantania JJE, Mongan SP. Lipid Profile, Blood Glucose Level and Body Mass Index (BMI) in Second Trimester of Pregnancy: Screening with Gestational Diabetes. Indones J Obstet Gynecol. 2020;8(1):34-43. doi:10.32771/inajog.v8i1.1093

11. Id TC, Id SAN, Levitt NS. Progression to type 2 diabetes mellitus and associated risk factors after hyperglycemia first detected in pregnancy: A cross-sectional study in Cape Town, South Africa. Published 
online 2019:1-18.

12. Yong HY, Mohd Shariff Z, Mohd Yusof $\mathrm{BN}$, et al. Independent and combined effects of age, body mass index and gestational weight gain on the risk of gestational diabetes mellitus. Sci Rep. 2020;10(1):1-8. doi:10.1038/s41598-

020-65251-2 